\title{
Analysis on the Types of Lace and Drawnwork Introduced to Shanghai
}

\author{
Huicui Miao ${ }^{1} \&$ Feng Zhao ${ }^{1,2}$ \\ ${ }^{1}$ School of Fashion and Art Design, Donghua University, Shanghai, China \\ ${ }^{2}$ China National Silk Museum, Hangzhou, China \\ Correspondence: Feng Zhao, China National Silk Museum, Hangzhou, China. Tel: 86-139-5806-6182. E-mail: \\ $1007043621 @$ qq.com
}

Received: January 2, 2022

Accepted: February 7, 2022

Online Published: February 28, 2022

doi:10.5539/ass.v18n3p8

URL: https://doi.org/10.5539/ass.v18n3p8

\begin{abstract}
Shanghai was an important lace export port in the early 20th century. Due to the lack of documentation, the historical research on the introduction of lace technology centered on Xujiahui Notre Dame is still not exhaustive. This article uses the latest collected literature as a supplement to verify and analyze the construction of the lace workshop of Notre Dame in Xujiahui, Shanghai. Based on the technical principles in the lace system, the time and variety of lace and drawnwork technology in the Shanghai area have been combed and researched, found that the varieties in the Shanghai area are relatively rich, of which the technical traditions of Needle lace and Crochet have been formed very early. As a famous lace variety in Shanghai, the introduction time of Filet lace is not synchronized with the first two.
\end{abstract}

Keywords: lace, Shanghai, Xujiahui Notre Dame

\section{Preface}

Lace and Drawnwork are traditional Western handicrafts. They were introduced into China from Yantai, Shanghai, Shantou and other places from Western countries at the end of the 19th century. Shandong, Shanghai and other places are customary to call it "Huabian". The Xujiahui Notre Dame in Shanghai has always been considered the birthplace of Shanghai lace technology. The lace industry in the surrounding areas of Shanghai in the early 20th century was inseparable from the shadows of Xujiahui merchants and women in Notre Dame. It is precisely because of this technological foundation that Shanghai gradually developed into China's important lace export port in the early 20th century.

\section{The History of the Establishment of Lace Workshop in Xujiahui Notre Dame}

Regarding the lace workshop in Xujiahui Notre Dame, a piece in Xuhui Jilue records "Notre Dame was founded in the fifth year of Xianfeng in the former Qing Dynasty (1855)...internal division...embroidery, lace room, tailor made, Laundry factory, etc.". Articles in recent years stated "Shortly after the completion of the Notre Dame in 1869 , an embroidery workshop was established here. The workers in the workshop were married orphans. Soon after, the lace workshop was also established." It can be seen that the lace workshop in Notre Dame is a separate workshop different from the embroidery workshop. In terms of the establishment time, the research materials basically only provide the completion status of Notre Dame, but there is no clear concept of the specific opening time of the lace workshop.

A French report in 1906. According to the information provided in the report, it can be understood that the initial workshop was a collection of sewing, knitting, embroidery, and lace. However, lace technology was not taken seriously at the time and was once stagnant. Lace really began to be noticed and mass production was carried out under the leadership of Mother St. Domincic. Mother St. Domincic arrived in Shanghai in 1871 and served as the dean of Notre Dame in Xujiahui during that time. She died in Shanghai in 1927. Recorded in the obituary article of Mother St. Domincic, she introduced the women's education and other work during her stay in China. At that time, there were lace and embroidery rooms. In 1935, Mother Mary of St. Austin published a biography of Mother St. Domincic in London, recording his missionary career in China for more than 50 years. This biography mentions the construction of Notre Dame's lace workshop.

Two years after the establishment of the original handicraft workshop (1895), Mother St. Domincic began to supervise school affairs as the Dean of Notre Dame. At this time, women were mainly employed to sew clothing, 
and their business was relatively bleak. Under this circumstance, Mother St. Domincic prayed. In this prayer, Mother St. Domincic received divine enlightenment and was told to do her best for this cause. After that, a lady who visited Notre Dame asked if they could mend their handkerchiefs, because these handkerchiefs were so delicate that they dared not hand over to the weavers to repair them. This made Dominican Mum begin to build confidence in the handmade workshop.

The real lace workshop was only established in 1896. In this year, Mother St. Domincic saw a girl from the United States, Annette, teaching several little orphans to make lace while visiting Notre Dame. So Mother St. Domincic immediately set out to set up a studio for the production of exquisite handmade lace, the studio established at this time will be the lace workshop of Notre Dame in the future.

The development of the lace of Notre Dame has always been inseparable from the patronage of European women who come to Shanghai. The ladies in Shanghai not only promote the lace production of Notre Dame, but also provide suggestions and lace samples. In the early years of the 20th century, buyers of Notre Dame's lace workshop included officers, captains, and consuls from other ports such as Tianjin, France, Germany, Portugal, and the United States who visited Xujiahui. In the Western travel notes at that time, Xujiahui lace was considered a must-buy specialty product in the local area. By 1910, Xujiahui had 624 people in the lace workshop, 91 in the embroidery room, 68 in the laundry room, and 58 in the sewing room, we can see the prosperity of the lace at that time. With the extensive development of lace production, the management of the lace workshop has gradually become formal. Not only has the apprenticeship system emerged, but also regulations similar to the full attendance reward mechanism. This reward mechanism is to counteract the labor demand that appears in large numbers of knitwear merchants in the winter from September to November every year, and to ensure that workers will regularly appear in the lace workshop during these months. In addition, due to the charitable nature of religion, Xujiahui's handicraft workshops, including the Lace workshop, will provide assistance to women workers' marriage, child care and other issues.

\section{Types of Products Made in Shanghai}

\subsection{Crochet and Knitting Technology in Shanghai}

In the Shanghai area, the crochet lace represented by "Xinzhuang crochet" is a branch of the western lace system. This type of lace uses a crochet needle as a tool and uses a thread to form the unique hole effect of lace products through regular knitting and empty stitch. Knitting is also similar to this. It still uses one thread for knitting, but the production tool is changed to two needles. Lace products made by this type of craft are called "knit lace". Different from other laces, the basic technical principles of the two types of lace belong to independent fabric production processes. Knitting and crochet technology have a long history of development. For example, crochet technology has appeared in the 16th century, but it was not until the 19th century that it began to be used to imitate lace products and eventually became independent Lace variety. In the literature in 1895, it was mentioned that schools in Shanghai area taught knitting and crochet techniques, but it did not mention lace making. The category name is likely to be a simple fabric technique, not the lace technique referred to in this article.

After these two types of technologies entered Shanghai, their development directions gradually diverged. In the later literature, the reference to knitting has always been simply "knit", and there has never been a name suggestive of lace. The crochet technique soon appeared under the name of Irish lace (Guipure d'llrlande/ Irish lace). In the 1920 literature, the use of "Irish Crochet" further clarified the relationship with crochet lace and Irish lace. The so-called Irish (crochet) lace is the most famous crochet lace variety in the lace system. This lace variety was introduced to Ireland from France in the 19th century. It was originally used to imitate the traditional Venice lace, later widely welcomed by the market, and gradually known as Irish crochet lace. Therefore in the Shanghai area, both knitting technology and crochet technology had been introduced before 1895, but there is no evidence that knitted lace varieties were introduced to Shanghai. The crochet lace variety was introduced to the Xujiahui area of Shanghai before 1906, and the early variety made was Irish crochet lace.

\subsection{Drawnwork and Cutwork}

Drawnwork and cutwork are important varieties of technologies related to lace in China. Among them, the best drawnwork production center is the Chaoshan area. The Changshu area, where the technique has been learned from Shanghai, is best known for cut work. Because these two types of varieties are not Shanghai's specialty varieties, they are rare in early records. Drawnwork was introduced to Shanghai very early, while the production time of cutwork as an independent variety in Shanghai was relatively late. As early as 1905, the report mentioned that local girls made drawnwork works, this technology should have been introduced to the local area before this. The cutwork were mentioned late. In the 1926 report, the cutwork products were considered to be mainly produced in the Shanghai area. It can be seen that the cutwork production in Shanghai was basically mature at 
that time.

Combined with the analysis of the introduction of "Changshu Huabian", which is now good at cutwork. The "Changshu Huabian" was introduced to the local area by Ji Genxian and Zhao Ni in 1917 and 1922 respectively. In records, the technique learned by Ji Genxian is called hand-embroidered lace while Zhao Ni's lace is called Venise lace. It can be inferred that the technique learned by Ji Genxian at that time belonged to the variety of cutwork that was more integrated with embroidery.

\subsection{Needle Lace}

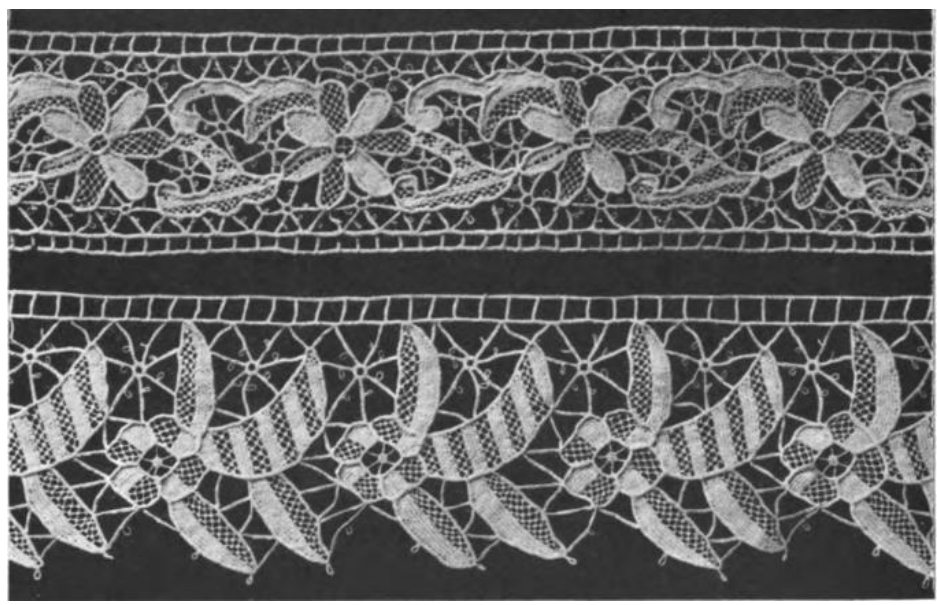

Figure 1. Venise Lace in Shanghai Lace Advertising

The most famous lace variety in Shanghai is the lace called "Wanlvsi" by Xiaoshan and other places. This is the transliterated name of Venice, and the type of lace referred to Venetian lace. Venetian lace is a complicated term in Western lace system, because Venetian lace can refer to all the local lace varieties made in Venice. It can be all lace varieties in Venice. Among them, needle lace is the most famous, but in the literature of that year, there is no more detailed description of this kind of lace. In the 1906 article, point de Venise appeared together with point à l'aiguille and dentelle Renaissance. All three types of lace use needle lace technology. In subsequent documents, the use of point de Venise and Venise laces often appeared, and later Chinese documents translated them into "Wannixun", "WanLisi", etc., which is the same as "Wanlvsi". Literature in 1923 Shows this so-called Venetian lace (Figure 1). It can be seen that the stitches of the Venetian lace at that time are very similar to those of the "Vanlvsi" lace made in Xiaoshan and other places. Various mesh stitches and side-step stitches can be found in the current Xiaoshan lace stitching. The patterns made by it are mainly flower patterns, which are connected at the bottom of the side-step stitches. The edge contour of the pattern is relatively thick but there is no obvious protrusion of the convex edge lace. Therefore, it can be judged that this kind of velvet lace introduced from Shanghai belongs to the flat needle lace in the western lace system.Since the most famous type of needle lace in Venice at the end of the 19th century and the beginning of the 20th century was made by the lace school on Brano Island, the Venetian lace learned in Shanghai is very likely to be the brano lace at that time.

\subsection{Filet Lace}

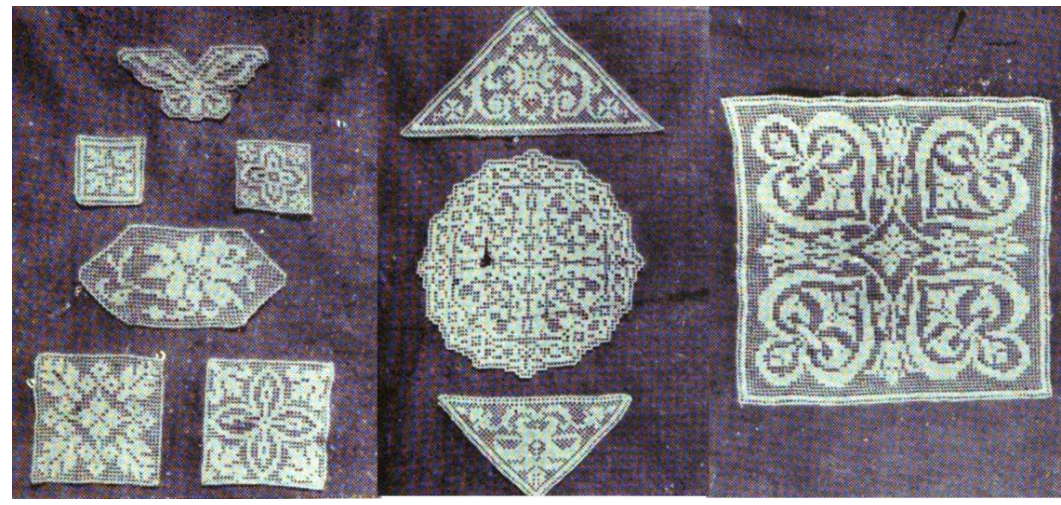

Figure 2. Filet Lace in Shanghai Lace Advertising 
Filet lace (Figure 2) was introduced to Shanghai relatively late, and the literature only began to appear in the 1910s. This kind of lace is one of the few introduced varieties in Shanghai that has a smaller relationship with Xujiahui. The introduction of this type of lace is detailed in the literature of the Republic of China. In the early 1910s, Gu Shaoye, a native of Shanghai, initiated the production of Filet lace. The lace company established in 1913 specialized in production and sales of this type of lace. Filet lace production is divided into two parts: netting and embroidery. It was first developed in Qingpu generation, and then gradually expanded to Ningbo and other places. The process of netting was gradually handed over to low-cost areas such as Ningbo. Only Qingpu district convened workers to carry out embroidery work. Due to the popularity of Filet lace, mosaic began to appear in Shanghai in the 1920s. This craft is also embroidered on the net, but the net is not formed by knotting, but on a plain weave fabric. Based on the time analysis of the appearance of this type of handicraft, it can be considered that mosaic were introduced into China to make similar products after the popularity of Filet lace.

\section{Conclusion}

The introduction of lace in Shanghai is centered on Notre Dame in Xujiahui. Under the impetus of Mother St. Domincic, Notre Dame has gradually developed a professional lace workshop from the early comprehensive manual workshop. In this lace workshop, there are a lot of lace like Varieties were introduced, among which crochet lace and Needle lace were the earliest and most famous lace varieties introduced. Filet lace was also extremely popular in foreign markets, but the introduction time was nearly ten years later than the previous two. Drawnwork and other needlework were introduced in Shanghai earlier, but they are not the main lace products in Shanghai; cutwork, mosaic and others are also introduced in Shanghai, but only as supplementary products in Shanghai. Knitting as a craft technology was introduced in Shanghai very early, but it did not develop lace production like crochet lace. But knitting technology eventually developed into an important textile technology branch in Shanghai. It can be seen that the variety of lace introduced in Shanghai is relatively comprehensive, and crochet, Needle lace, and Filet lace are important products. Although lace technology has gradually spread to the Jiangsu area around Shanghai. The birthplace of Shanghai and Xujiahui is still an important technological position of lace technology.

\section{References}

Elwin, M. R. M. (1906). The industrial department of an orphanage. Records of the Fifth Triennial Meeting of the Educational Association of China, (5), 299-300.

Feng, Z. H. (2018). Research on History of Women Workers' Workshop of Xujiahui Notre Dame. Shanghai Arts \& Crafts, (3), 29-21. Retrieved from http://CNKI:SUN:SGYM.0.2018-03-010

Laces and Embroideries: Notes Gain in Imports of Chinese Lace and Embroidery Products. (1926). Women's Wear, p. 32.

Les ouvroirs des religieuses auxiliatrices a Zi-ka-wei. (1906). Relations de Chine, (7), 164.

Liu, L. S. (1927). The situation of the former Dean Mother St. Domincic of Zi-ka-wei Sen-mou-ieu. Alumni Association Journal of L'Étoile du Matin, (3), 1-4.

Mother Mary of St.Austin. (1935). Fifty-six years a missionary in China; the life of Mother St. Domincic, helper of the holy souls. London: Burns, Oates \& Washbourne.

Shanghai Local History Office. (2006). Xuhui Jilue. Shanghai: Shanghai Academy of Social Sciences Press.

Yao, J. Z., Jiang, G. M., \& Liu, T. L. (2011). Origin and development of modern lace in Shanghai. Journal of Silk, (8), 50-53. https://doi.org/10.3969/j.issn.1001-7003.2011.08.013

\section{Copyrights}

Copyright for this article is retained by the author(s), with first publication rights granted to the journal.

This is an open-access article distributed under the terms and conditions of the Creative Commons Attribution license (http://creativecommons.org/licenses/by/4.0/). 